Volume. 2 Nomor. 2

Periode: Juli - Desember 2018; hal. 39-57

p-ISSN : 2580-1112; e-ISSN : 2655-6669

Copyrighr@2018

Penulis memiliki hak cipta atas artikel ini

Jurnal Ilmiah Keperawatan Orthopedi (JIKO)

journal homepage:

https://ejournal.akperfatmawati.ac.id

\title{
Efektifitas Terapi Slow Stroke Back Massage Terhadap Tekanan Darah Pada Lansia di RW 001 Kelurahan Jombang Kecamatan Ciputat Kota Tangerang Selatan
}

\author{
Dwinta Nuke Kusumoningtyas ${ }^{1}$, Diah Ratnawati ${ }^{2}$ \\ Fakultas Ilmu Kesehatan, Universitas Pembangunan Nasional Veteran Jakarta
}

\begin{abstract}
Abstrak
Menua merupakan suatu proses akumulasi secara progresif dari berbagai perubahan fisiologi organ tubuh. Perubahan fisiologi ini salah satunya adalah gangguan sirkulasi darah karena menurunnya elastisitas arteri yang berakibat terjadinya hipertensi. Lansia yang mengalami hipertensi dapat mengakibatkan komplikasi gagal jantung dan menurunnya kualitas hidup di usia senja. Salah satu cara untuk mengatasi hipertensi yang dialami oleh lansia adalah terapi slow stroke back massage. Penerapan ini bertujuan untuk mengatahui pengaruh pemberian terapi slow stroke back massage dalam menurunkan tekanan darah pada lansia di RW 001 Kelurahan Jombang Kecamatan Ciputat Kota Tangerang Selatan. Desain yang digunakan Quasi Experiment dengan rancangan Pretest and Posttest non Equivalent Control Group dan jumlah sampel sebanyak 30 responden. Hasil penelitian menunjukkan nilai yang signifikan antara pre-post sistol kelompok intervensi sebesar 0,000 $(p<0,05)$ dan signifikan antara pre-post diastol kelompok intervensi sebesar 0,000 $(p<0,05)$. Hasil pada kelompok kontrol menunjukkan nilai yang tidak signifikan pada pre-post sistol dengan $p$ value $0,197(\mathrm{p}>0,05)$ dan nilai yang tidak signifikan pada pre-post diastol dengan nilai $p$ value $0,334(\mathrm{p}>0,05)$. Kesimpulannya bahwa ada pengaruh slow stroke back massage dalam mengatasi tekanan darah pada lansia. Hasil penelitian ini diharapkan perawat dan lansia dapat mengatasi hipertensi secara mandiri dengan menerapkan terapi slow stroke back massage.
\end{abstract}

Kata kunci: Hipertensi, Lansia, Slow Stroke Back Massage, Tekanan Darah

\begin{abstract}
Aging is a process of progressive accumulation of various changes in the physiology of organs. One of physiological changes is a disorder of blood circulation due to decreased elasticity of the arteries resulting in the occurrence of hypertension. Elderly with hypertension can lead to complications of heart failure and decreased quality of life in old age. One way to overcome the hypertension experienced by the elderly is the therapy of slow stroke back massage. This application aims to know the effect of slow stroke therapy back massage in lowering blood pressure in the elderly in RW 001 Jombang Ciputat Tangerang Selatan. The design used Quasi Experiment with Pretest and Posttest non Equivalent Control Group and the total of 30 respondents. The results showed a significant value between the pre-post systole intervention group of $0,000(p<0,05)$ and significantly between

1,2 e-mail: ratnawatidiah@yahoo.co.id
\end{abstract}


the pre-post diastole intervention group of $0,000(p<0,05)$. Results in the control group showed insignificant values in pre-post systole with $p$ value 0,197 $(p>0,05)$ and insignificant value in pre-post diastole with $p$ value 0,334 ( $>>0,05)$. In conclusion that there is the influence of slow stroke back massage in overcoming blood pressure in the elderly. The results of this study is expected nurses and elderly can overcome hypertension independently by applying slow stroke therapy back massage.

\section{Keyword: Blood Pressure, Elderly, Hypertension, Slow Stroke Back Massage}

\section{Pendahuluan}

Lansia merupakan bagian dari proses fisiologi tumbuh kembang, dimana manusia bertumbuh dan berkembang dari bayi, anak-anak, dewasa dan akhirnya menjadi tua. Lansia merupakan suatu proses alami yang tidak dapat dihindari oleh semua orang dan di masa ini seseorang mengalami kemunduran fisik, mental dan sosial secara bertahap (Azizah, 2011).

Pada tahun 2010 menunjukkan bahwa presentase penduduk lanjut usia akan mencapai $9,77 \%$ dari total penduduk dan menjadi $11,34 \%$ pada tahun 2020 (Menegpp, 2009). Di Indonesia, jumlah penduduk lanjut usia menjadi 18,781 juta jiwa pada tahun 2014 dan diperkirakan pada tahun 2025, jumlahnya akan mancapai 36 juta jiwa (KemenKes, 2015).

Menua merupakan suatu proses fisiologi yang mengalami berkurangnya daya tahan tubuh dalam menghadapi rangsangan atau perubahan dari internal dan eksternal tubuh manusia. Proses menua merupakan kumpulan suatu gejala secara progresif atau bertahap dari perubahan fisiologi organ tubuh seseorang yang berlangsung secara terusmenerus dan proses menua akan meningkatkan kemungkinan terkena berbagai penyakit karena perubahan sistem organ tubuh (Azizah, 2011).

Penyakit pada lansia yang biasanya dijumpai dalam proses menua sebagian besar dikelompokkan menjadi beberapa jenis yaitu gangguan sirkulasi darah, gangguan metabolisme hormonal, gangguan persendian dan berbagai macam neoplasma.

Gangguan pada sirkulasi darah, yaitu salah satunya penyakit hipertensi
(Azizah, 2011). Penyakit hipertensi termasuk ke dalam penyakit tidak menular (PTM) dan hipertensi ini merupakan penyakit yang sering ditemukan pada lansia. Hipertensi pada lansia secara teori terjadi karena menurunnya elastisitas arteri yang disebabkan oleh proses menua, selain faktor elastisitas dapat terjadi karena gaya hidup lansia itu sendiri (Wahyunita dan Fitrah, 2010).

Penyakit jantung dan serebrovaskuler merupakan penyebab terbanyak kematian pada usia diatas 60 tahun dan kematian akibat penyakit kardiovaskuler dapat menurun dengan pengobatan penyakit hipertensi (Azizah, 2011). Di dunia, terdapat 7,5 juta kematian akibat hipertensi atau sekitar $12,8 \%$ dari total kematian. 57 juta jiwa mengalami disability adjusted life years (DALY).

Pada tahun 2011 hingga 2012 terdapat sekitar $25 \%$ orang dewasa di United State menderita penyakit hipertensi. Antara laki-laki dan perempuan tidak ada perbedaan prevalensi penderita hipertensi hanya saja prevalensi tersebut terus meningkat berdasarkan usia : 5\% usia 20-39 tahun, 26\% usia 40-59 tahun dan 59,6\% untuk usia 60 tahun keatas (Aoki, dkk., 2014).

Pada pelayanan kesehatan primer penderita hipertensi banyak dijumpai hal ini merupakan tantangan besar bagi Indonesia. Hipertensi memiliki prevalensi yang tinggi, yaitu sebesar $25,8 \%$ (RIKESDAS, 2013). Jumlah penderita hipertensi di dunia dan di Indonesia sangat besar, hal ini akan berdampak pada beberapa aspek. Salah satunya yaitu dampak fisiologis lansia akan 
menimbulkan gagal jantung, gagal ginjal dan penurunan kualitas hidup diusia senja.

Dampak yang kedua, pada keluarga yang harus merawat anggota keluarganya dan mengeluarkan dana yang tidak sedikit untuk biaya terapi farmakologi. Disamping itu pengontrolan hipertensi dengan terapi farmakologi belum adekuat meskipun sudah banyak tersedia obat-obatan yang efektif (Depkes RI, 2013).

Hipertensi merupakan faktor resiko utama penyakit kardiovaskuler pada lansia yang merupakan penyebab kematian tertinggi di Indonesia (Rikesdas, 2007). Penyakit hipertensi dan penyakit kardiovaskuler masih cukup tinggi dan bahkan cenderung meningkat seiring dengan gaya hidup yang jauh dari perilaku hidup bersih dan sehat serta mahalnya biaya pengobatan hipertensi.

Reaksi terhadap penyakit hipertensi berbeda tergantung pada koping lansia untuk mengontrol tekanan darahnya seperti mengurangi stress, penurunan berat badan, pembatasan natrium, olahraga serta terapi relaksasi yang merupakan intervensi wajib yang harus dilakukan pada setiap terapi hipertensi.

Fenomena yang terjadi di masyarakat bahwa pengobatan penyakit hipertensi yaitu dengan pemberian terapi farmakologi (obat-obatan) dan nonfarmakologi (perubahan gaya hidup). Pemberian terapi farmakologi biasanya diberikan dengan obat-obatan anti hipertensi yang sering digunakan dalam pengobatan antara lain obat-obatan diuretik, bata bloker, antagonis kalsium, dan penghambat konversi enzim angiotensin (Casanelia. 2010). Untuk pemberian terapi hipertensi non farmakologi dengan pembatasan asupan garam dan natrium, serta upaya penurunan bobot badan merupakan langkah awal dalam pengobatan hipertensi, sedangkan terapi non farmakologis lainnya adalah berolahraga secara teratur, berhenti merokok, tidak minum minuman alkohol, menghindari stres dan obesitas.

Pendapat lain dari Muttaqin (2009) bahwa terapi non farmakologi adalah terapi herbal, perubahan gaya hidup, kepatuhan dalam pengobataan, pengendalian stres dan terapi relaksasi. Untuk membuat tubuh menjadi rileks dapat dilakukan dengan cara seperti terapi musik klasik, yoga, tehnik nafas dalam dan terapi massage.

Penatalaksanaan nonfarmakologi dalam fundamental of nursing strategi pada pasien hipertensi dapat diterapkan berbagai tindakan keperawatan holistik, pada implementasi terapi holistik di Indonesia adalah asuhan keperawatan yang didasarkan kepada perawatan pasien secara total yang mempertimbangkan kebutuhan fisik, emosi, sosial, ekonomi dan spiritual seseorang penggunaan herbal, penerapan konsep hidup sehat dan relaksasi seperti dapat diberikan massage (Perry \& Potter, 2005). Retno (2012) dalam penelitiannya mendapatkan hasil bahwa massage merupakan terapi non farmakologi yang sangat efektif dalam menurunkan tekanan darah sistolik dan diastolik pada pasien hipertensi.

Menurut Alikin (2014), massage adalah tehnik penyembuhan yang diterapkan kedalam bentuk sentuhan langsung dengan tubuh penderita untuk memberikan efek relaksasi melalui mechanoreseptor tubuh yang mengatur kehangatan, tekanan dan sentuhan menjadi mekanisme relaksasi.

Cassar (2007) menyatakan bahwa tehnik massage berupa intervensi Slow Stroke Back Massage (pijat lembut pada punggung) dapat meningkatkan relaksasi dengan menurunkan aktivitas saraf simpatis dan meningkatkan aktivitas saraf parasimpatis sehingga terjadi vasodilatasi diameter arteriol. Selain terjadi vasodilatasi diameter arteriol, implikasi keperawatan slow stroke back massage dapat menurunkan tekanan darah, frekuensi jantung dan suhu tubuh (Smeltzer, 2010). 
Hasil survei pendahuluan yang praktikkan lakukan di RW 001 Kelurahan Jombang, Kecamatan Ciputat, Kota Tangerang Selatan pada bulan Maret 2017 didapatkan data jumlah lansia yang menderita hipertensi sebanyak 102 dari 5 RT yaitu RT 01, 02, 03, 04 dan 05. Hasil wawancara interpersonal kepada 10 lansia didapatkan data bahwa sebanyak 7 lansia (70\%) menyatakan bahwa peningkatan tekanan darah memang wajar diusia lansia karena proses penuaan dan mengatasi gejala peningkatan tekanan darah dengan minum obat secara teratur serta mengontrol emosi.

Data lain yaitu sebanyak 3 lansia $(30 \%)$ mengatakan cara mengatasi peningkatan tekanan darah dengan mengkonsumsi makanan yang rendah garam. Selain itu, lansia juga mengatakan takut jika harus mengkonsumsi obat penurun tekanan darah karena dapat menimbulkan efek samping. Ketika ditanya terkait terapi relaksasi slow stroke back massage untuk menurunkan tekanan darah tinggi, lansia menyatakan bahwa tidak mengetahui terapi relaksasi ini dapat menurunkan tekanan darah.

$$
\text { Tanpa diimbangi dengan }
$$

persiapan dalam menghadapi usia tua dapat menyebabkan penurunan kualitas hidup di usia senja. Maka dari itu, perawat memiliki peran yang penting dalam tindakan asuhan keperawatan khususnya merawat lansia dengan hipertensi yaitu sebagai pemberi asuhan keperawatan langsung (Care giver), pendidik klien lansia (Edukator), advokasi klien (Client advocate) dan konselor (Consultant).

Peran perawat dalam komunitas yaitu memberikan asuhan keperawatan langsung (care giver) pada pasien khususnya pasien lansia dengan hipertensi yaitu berupa pencegahan primer, pencegahan sekunder dan pencegahan tersier.

Asuhan keperawatan dalam pencegahan sekunder pada lansia dengan hipertensi salah satunya dengan pemberian terapi modalitas (Ayu, 2011). Terapi modalitas pada lansia dengan hipertensi yaitu terapi relaksasi. Relaksasi yang dapat dilaksanakan salah satunya dengan cara massage.

Massage dapat memberikan relaksasi melalui mechanoreceptors tubuh yang mengatur kehangatan, tekanan dan sentuhan menjadi mekanisme relaksasi, selain itu dapat terjadi hubungan saling percaya antara pasian dengan perawat. Mechanoreceptors adalah sel yang menstransduksi rangsangan mekanik yang dihasilkan dangan cara massage dan menyampaikan sinyal ke sistem saraf pusat untuk menurunkan tekanan darah.

Massage terdiri dari banyak jenis metode aplikasi yang digunakan sebagai media penyembuhan penyakit. Salah satu metode yang dapat digunakan dalam massage yaitu slow stroke back massage dengan teknik massage berupa selang seling tangan, remasan, gesekan, eflurasi, petriasi dan tekanan menyikat (Purwanto, 2013).

Mekanisme slow stroke back massage adalah pada pelepasan endorphin, vasodilatasi sistemik dan penurunan kontraktilitas yang terjadi akibat peningkatan aktivitas sistem saraf parasimpatis yang mengeluarkan neurotransmitter asetilkolin yang dapat menghambat depolarisasi $S A$ node dan $A V$ node yang berakibat pada penurunan aktivitas sistem saraf simpatis sehingga menimbulkan dampak penurunan kecepatan denyut jantung, curah jantung dan volume sekucup sehingga terjadi penurunan tekanan darah (Muttaqin, 2009).

Berdasarkan hal tersebut di atas maka penulis menganalisa efektifitas terapi slow stroke back massage terhadap tekanan darah pada lansia di RW 001 Kelurahan Jombang, Kecamatan Ciputat, Kota Tangerang Selatan.

\section{Metode Penelitian}

Penelitian ini menggunakan desain quasi experimental pre and post test with control group dengan intervensi terapi slow stroke back massage. 
Penelitian ini membandingkan antara kelompok kontrol dan kelompok intervensi pada lansia dengan hipertensi sebelum dan sesudah dilakukan terapi slow stroke back massage di RW 001 Kelurahan Jombang, Kecamatan Ciputat, Kota Tangerang Selatan. Hal tersebut bertujuan untuk menganalisa efektifitas terapi slow stroke back massage terhadap tekanan.

Populasi pada penerapan evidence baser nursing ini adalah lansia dengan hipertensi yang berada di RW 001 Kelurahan Jombang, Kecamatan Ciputat, Kota Tangerang Selatan, dari hasil survei didapatkan jumlah lansia penderita hipertensi di RW 001 Kelurahan Jombang Kecamatan Ciputat Kota Tangerang Selatan sebanyak 102 orang. Hasil penelitian Moheibi, dkk (2014) diperoleh penurunan rata-rata tekanan darah sistolik sebesar $9,87 \mathrm{mmHg}$ dengan standar deviasi 12,47.

Sampel dibagi atas 2 kelompok yaitu 15 orang untuk kelompok intervensi dan 15 orang untuk kelompok control. Jadi total responden sebanyak 30 orang. Slow Stroke Back Massage dilakukan pada lansia dengan hipertensi yang berada di RW 001 Kelurahan Jombang, Kecamatan Ciputat, Kota Tangerang Selatan pada bulan Maret 2017 hingga Mei 2017.

Penelitian ini melakukan analisa univariat untuk mengetahui distribusi karakteristik (usia, jenis kelamin, pendidikan, pekerjaan dan status perkawinan) dan distribusi tekanan darah sebelum dan sesudah dilakukan terapi slow stroke back massage pada kelompok intervensi dan kelompok kontrol pada lansia dengan hipertensi di RW 001 Kelurahan Jombang, Kecamatan Ciputat, Kota Tangerang Selatan. Selain itu, analisa bivariat untuk menganalisa efektifitas terapi relaksasi slow stroke back massage terhadap tekanan darah pada lansia di RW 001 Kelurahan Jombang, Kecamatan Ciputat, Kota Tangerang Selatan tahun 2017 sebelum dan sesudah diberikan terapi dengan menggunakan uji T-test.

Tahap awal, peneliti melakukan kontrak waktu dengan lansia dan kepada pihak RW sebelum pelaksanaan penelitian. Tahap pelaksanaan, peneliti menjelaskan tujuan dan prosedur penerapan yang didahului dengan kegiatan penyuluhan hipertensi kepada kedua kelopmpok. Setelah itu, lansia diminta untuk menandatangani lembar persetujuan untuk menjadi responden. Kemudian praktikkan memberikan kuesioner untuk melihat data demografi. Kelompok intervensi diberikan penjelasan prosedural terapi relaksasi slow stroke back massage dengan pemberian terapi selama 12 kali pertemuan dalam waktu tiga minggu selama 10 menit tiap pertemuan. Kemudian, peneliti memberikan contoh gerakan teknik relaksasi slow stroke back massage kepada keluarga lansia baik melalui gerakan secara langsung maupun dengan gambar.

Prosedur teknik relaksasi slow stroke back massage yang akan dilakukan adalah sebagai berikut, gerakan pertama; teknik masase dengan gerakan tangan selang-seling (tekanan pendek, cepat dan bergantian tangan) dengan menggunakan telapak tangan dan jari dengan memberikan tekanan ringan. Gerakan ini dilakukan sebanyak 10 kali dalam waktu 1 menit 40 detik. Gerakan kedua; teknik remasan (mengusap otot bahu), dengan satu tangan menekan dan tangan satunya mencekram daging. Angkat jaringan sambil diputar. Lepaskan daging dan cengkeram dengan tangan satunya. Gunakan kedua tangan secara bergantian dengan cara gerakan berirama seolah-olah sedang menguleni adonan roti atau memeras kain basah. Setelah itu peras dan lepaskan daging dengan cara gerakan perlahan agar tidak terasa seperti mencubit. Gerakan ini dilakukan sebanyak 10 kali dalam waktu 1 menit 40 detik.

Gerakan ketiga; teknik masase dengan cara menggesekkan ibu jari 
dengan gerakkan memutar atau sirkuler. Setelah itu dorong daging ke arah luar dengan menggunakan ibu jari secara bergantian dalam gerakan setengah lingkaran atau lurus berirama. Kemudian kedua ibu jari bergantian memutar daging ke arah luar. Gunakan berat tubuh untuk memperdalam tekanan gerakkan, lakukan gerakan ini secara perlahan. Gerakan ini dilakukan sebanyak 10 kali dalam waktu 1 menit 40 detik. Gerakan keempat; teknik eflurasi dengan kedua tangan. Memberikan sentuhan sedikit menekan dari arah bokong hingga pundak. Lakukan secara perlahan. Gerakan ini dilakukan sebanyak 10 kali dalam waktu 1 menit 40 detik.

Gerakan kelima; teknik petrisasi dengan menekan punggung secara horizontal. Gerakan ini dilakukan sebanyak 10 kali dalam waktu 1 menit 40 detik. Gerakan keenam; teknik tekanan menyikat dengan menggunakan ujung jari, digunakan pada akhir masase dan berikan sentuhan masase memutar untuk mengakhiri masase. Gerakan ini dilakukan sebanyak 10 kali dalam waktu 1 menit 40 detik (Potter \& Perry, 2005).

Pemberian terapi slow stroke back massage dilakukan selama 3 minggu yang terbagi menjadi 12 kali pertemuan, dengan waktu 10 menit selama 1 kali pertemuan. Setelah diberikan intervensi terapi relaksasi slow stroke back massage selama 10 menit setiap pertemuan, maka responden dilakukan pengecekan tekanan darah kembali menggunakan sphygmomanometer. Tindak lanjut merupakan tahapan setelah tahap evaluasi. Pada tahap ini peneliti menindaklanjuti hasil dari pemberian terapi slow stroke back massage ini baik yang berhasil dari tujuan pemberian terapi maupun sebaliknya.

\section{Hasil Penelitian dan Pembahasan Karakteristik Responden}

\section{Usia}

Berdasarkan tabel distribusi frekuensi berdasarkan usia responden di RW 001 Kel. Jombang Kec. Ciputat Kota
Tangerang Selatan $(n=30)$, diperoleh ratarata (mean) dari usia responden kelompok intervensi adalah 57,93 dengan standar deviasi 4,590. Usia termuda responden adalah 50 tahun dan usia tertua responden adalah 65 tahun. Selain itu, rata-rata (mean) dari usia responden kelompok kontrol adalah 55,67 dengan standar deviasi 4,701. Usia termuda responden adalah 49 tahun dan usia tertua responden adalah 63 tahun.

Data diatas sejalan dengan penelitian dari Fredy (2011) yang berjudul "Pengaruh Pemberian Massage Punggung terhadap Tekanan Darah pada Pasien Hipertensi" didapatkan hasil usia yang rentan yang mengalami hipertensi yaitu responden yang berumur $>40$ tahun sekitar $40 \%$ dikarenakan berkurangnya elastisitas arteri, kekakuan pada pembuluh darah dan adanya pengaruh hormon (Admin, 2013).

Dampak dari ketidakefektifan elastisitas dan terjadinya kekakuan pada pembuluh darah mengakibatkan tekanan darah sistolik dan tekanan darah diastolik meningkat (Kozier, 2009). Begitu juga dengan penelitian yang dilakukan Anggara dan Prayitno (2013) tentang faktor-faktor yang berhubungan dengan tekanan darah di puskesmas Telaga Murni, Cikarang Barat tahun 2012 didapatkan hasil dari 34 responden yang menderita hipertensi menunjukkan bahwa sebagian besar responden berusia $>40$ tahun sebesar 55,9\%.

Namun, hasil penelitian tidak sejalan yang dilakukan dengan pengukuran tekanan darah pada penduduk usia 18 tahun di Indonesia menunjukkan prevalensi sebesar $31,7 \%$. Hal ini dikarena dampak dari konsumsi rokok $(9 \%)$, diabetes $(6 \%)$, kurang olahraga (5\%) dan obesitas (5\%) (Depkes RI, 2008).

Terjadinya hipertensi seiring dengan bertambahnya usia maka resiko untuk menderita penyakit hipertensi juga semakin meningkat, meskipun penyakit hipertensi bisa terjadi pada segala usia tetapi paling sering dijumpai pada orang 
berusia 35 tahun ke atas. Usia 65 tahun ke atas setengahnya menderita hipertensi diantara orang Amerika baik yang berkulit hitam maupun berkulit putih (Sheps, 2011).

Usia rata-rata responden pada tempat penelitian tersebut masuk dalam kategori usia pertengahan (middle age). Hal tersebut dinyatakan oleh WHO (2009) usia pertengahan (middle age) berkisar mulai dari 45-59 tahun, usia lanjut (fiderly) antara 60-74 tahun, lansia tua (old) berada diusia 75-90 tahun dan lansia sangat tua (very old) pada usia lebih dari 90 tahun. Jadi, sebagian besar responden lansia yang menderita hipertensi di RW 001 Kelurahan

Jombang, Kecamatan Ciputat, Kota Tangerang Selatan termasuk dalam kelompok usia pertengahan (middle age) yaitu berkisar 45-59 tahun.

Peneliti berasumsi bahwa hipertensi dapat diderita oleh siapapun tidak melihat usia terutama pada lansia yang sedang atau sudah mengalami proses penuaan, salah satunya berpengaruh terhadap mekanisme saraf simpatis yang berakibat perubahan pada pembuluh darah. Hal tersebut disebabkan oleh banyaknya faktor resiko (konsumsi garam berlebih, stres, obesitas dan merokok) yang memicu terjadinya peningkatan tekanan darah.

\section{Jenis kelamin}

Tabel 1 Distribusi Frekuensi Berdasarkan Jenis Kelamin Responden di RW 001 Kel. Jombang Kec. Ciputat Kota Tangerang Selatan $(n=30)$

\begin{tabular}{ccc}
\hline Jenis Kelamin & $\begin{array}{c}\text { Kelompok Intervensi } \\
\text { n (\%) }\end{array}$ & $\begin{array}{c}\text { Kelompok Kontrol } \\
\text { n (\%) }\end{array}$ \\
\hline Laki-laki & $3(20,0)$ & $6(40,0)$ \\
Perempuan & $12(80,0)$ & $9(60,0)$ \\
\hline Total & $\mathbf{1 5}(\mathbf{1 0 0 , 0})$ & $\mathbf{1 5}(\mathbf{1 0 0 , 0})$ \\
\hline
\end{tabular}

Berdasarkan tabel di atas, dapat diketahui bahwa 3 responden $(20,0 \%)$ berjenis kelamin laki-laki dan 12 responden $(80,0 \%)$ berjenis kelamin perempuan pada kelompok intervensi, serta 6 responden $(40,0 \%)$ berjenis kelamin laki-laki dan 9 responden $(60,0 \%)$ berjenis kelamin perempuan pada kelompok kontrol. Jenis kelamin merupakan identitas pada responden yang dapat digunakan untuk membedakan antara laki-laki dan perempuan dapat dilihat dari nilai, tingkah laku dan tampak fisik dari responden. Perbedaan jenis kelamin merupakan salah satu faktor yang dapat mempengaruhi psikologis seseorang.

Faktor psikologis tersebut, dapat mempengaruhi terhadap peningkatan tekanan darah, seseorang yang dapat mengontrol efek psikologis dapat relatif stabil tekanan darahnya dibandingkan dengan orang yang tidak dapat mengontrol efek psikologis (Lutfia dan Maliya, 2008). Jenis kelamin yang mempengaruhi faktor psikologis pada laki-laki secara umum dapat dipicu oleh perilaku tidak sehat seperti merokok, alkohol, kelebihan berat badan, depresi dan rendahnya status pekerjaan. Selain itu, pada wanita lebih berhubungan dengan pekerjaan yang mempengaruhi faktor psikis kuat (Sutanto, 2007).

Pada usia muda biasanya tidak ditemukan adanya perbedaan tekanan darah antara laki-laki dan perempuan kecuali jika dipengaruhi oleh faktor penyakit bawaan. Namun, pada saat usia selanjutnya (remaja), laki-laki cenderung memiliki tekanan darah yang lebih tinggi dibandingkan dengan perempuan hal ini belum dibuktikan dengan penelitian yang pasti. Perbedaan pada usia dewasa muda dan menengah tampak lebih jelas, namun perbedaan tersebut akan berbalik pada usia lanjut. Hal tersebut disebabkan oleh hormon estrogen yang dapat melindungi wanita dari penyakit kardiovaskuler (Essop \& Naidoo, 2008).

Hasil penelitian ini, tidak sejalan dengan pernyataan Fredy (2014) yang berjudul "Pengaruh Pemberian Massage 
Punggung terhadap Tekanan Darah pada Pasien Hipertensi" karena didapatkan sebanyak 23 responden $(71,9 \%)$ berjenis kelamin laki-laki. Namun, hasil ini juga didukung oleh penelitian Mohebbi (2014) mengenai "The effect of Back Massage on Blood Pressure in the Patients with Primary Hypertension in 2012-2013: A Randomized Clinical Trial" yang mendapatkan data bahwa pada perempuan yang mengalami menopause jumlah hormon estrogen dalam tubuhnya menurun sehingga kadar High Density Lipoprotein (HDL) dalam tubuh juga menurun, dikarenakan HDL juga berperan dalam pencegahan terjadinya

Tabel 2 Distribusi Frekuensi Berdasarkan Pendidikan Responden di RW 001 Kel. Jombang Kec. Ciputat Kota Tangerang Selatan $(\mathrm{n}=30)$

\begin{tabular}{ccc}
\hline Pendidikan & $\begin{array}{c}\text { Kelompok Intervensi } \\
\mathbf{n}(\boldsymbol{\%})\end{array}$ & $\begin{array}{c}\text { Kelompok Kontrol } \\
\mathbf{n}(\boldsymbol{\%})\end{array}$ \\
\hline SMP & $3(20,0)$ & $1(6,7)$ \\
SMA & $9(60,0)$ & $12(80,0)$ \\
Perguruan Tinggi & $3(20,0)$ & $2(13,3)$ \\
\hline Total & $\mathbf{1 5 ( 1 0 0 , 0 )}$ & $\mathbf{1 5}(\mathbf{1 0 0 , 0 )}$ \\
\hline
\end{tabular}

Berdasarkan tabel di atas, dapat diketahui bahwa 3 responden $(20,0 \%)$ berpendidikan SMP, 9 responden $(60,0 \%)$ SMA dan 3 responden $(20,0 \%)$ Perguruan Tinggi pada kelompok intervensi. Hasil penelitian juga terdapat 1 responden $(6,7 \%)$ berpendidikan SMP, 12 responden (80,0\%) SMA dan 2 responden $(13,3 \%)$ Perguruan Tinggi pada kelompok kontrol.

Pendidikan adalah salah satu faktor yang dapat mempengaruhi pengetahuan individu. Individu dengan pendidikan yang tinggi akan memiliki pengetahuan lebih banyak tentang bagaimana berperilaku hidup sehat dan menjaga kesehatan disetiap perkembangannya. Selain itu, pendidikan dan pengetahuan juga merupakan faktor aterosklerosis. Kadar HDL dalam tubuh yang menurun menyebabkan pembuluh darah mengalami penyempitan sehingga tekanan darah meningkat.

Peneliti berasumsi bahwa perbedaan hasil ini dikarenakan perbandingan jumlah responden lansia laki-laki dan lansia perempuan yang tidak proporsional. Responden lansia perempuan 2 kali lebih banyak dibandingkan dengan jumlah responden penerapan lansia laki-laki yaitu sebanyak 68 lansia perempuan dari total 102 lansia dengan hipertensi.

\section{Pendidikan}

yang mempengaruhi sikap dan perilaku individu dalam mencapai taraf kesehatan secara mandiri (Mubarak, 2007).

Peneliti berasumsi bahwa pendidikan mempengaruhi proses belajar, mayoritas pendidikan lansia di RW 001 Kelurahan Jombang, Kecamatan Ciputat, Kota Tangerang Selatan adalah SMA, maka makin mudah lansia tersebut menerima informasi dan akhirnya makin banyak pula pengetahuan yang dimilikinya terkait terapi slow stroke back massage dalam menurunkan tekanan darah. Pendidikan tinggi seseorang cenderung untuk mendapatkan wawasan sehingga berpengaruh terhadap perilaku positif terhadap kesehatan individu.

\section{Pekerjaan}

Tabel 3 Distribusi Frekuensi Berdasarkan Pekerjaan Responden di RW 001 Kel. Jombang Kec. Ciputat Kota Tangerang Selatan $(n=30)$

\begin{tabular}{ccc}
\hline Pekerjaan & $\begin{array}{c}\text { Kelompok Intervensi } \\
\text { n }(\boldsymbol{\%})\end{array}$ & $\begin{array}{c}\text { Kelompok Kontrol } \\
\text { n }(\%)\end{array}$ \\
\hline Bekerja & $10(66,7)$ & $11(73,3)$ \\
Tidak Bekerja & $5(33,3)$ & $4(26,7)$ \\
\hline Total & $\mathbf{1 5}(\mathbf{1 0 0 , 0})$ & $\mathbf{1 5}(\mathbf{1 0 0 , 0 )}$ \\
\hline
\end{tabular}


Berdasarkan tabel 10 di atas, dapat diketahui bahwa 10 responden $(66,7 \%)$ bekerja dan 5 responden $(33,3 \%)$ tidak bekerja pada kelompok intervensi, serta 11 responden $(73,3 \%)$ bekerja dan 4 responden $(26,7 \%)$ tidak bekerja pada kelompok kontrol. Responden yang masih aktif bekerja, mereka memiliki berbagai macam profesi yaitu sebagai guru, karyawan, PNS dan wiraswasta.

Hasil penelitian ini sejalan dengan penelitian yang dilakukan oleh Sigarlaki (2007) tentang "Karakteristik dan Faktor yang Berhubungan dengan Hipertensi di Desa Bocor, Kecamatan Bulus Pesantren, Kabupaten Kebumen" didapatkan hasil dari 102 responden sebagian besar responden memiliki pekerjaan dengan hipertensi grade 1 sebanyak 55 orang atau $53,91 \%$. Namun, tidak sejalan dengan data dari penelitian Zuraidah, dkk (2012) yang menyatakan bahwa penderita hipertensi yang tidak bekerja lebih banyak dibanding dengan yang bekerja yaitu sebanyak 91 responden $(56,9 \%)$ dan yang bekerja sebanyak 69 responden $(43,1 \%)$.

Pekerjaan berpengaruh terhadap aktivitas fisik seseorang. Orang yang tidak bekerja biasanya tidak memiliki aktivitas secara rutin sehingga dapat meningkatkan kejadian hipertensi. Hal ini tidak sejalan dengan penerapan yang dilakukan oleh Anggara dkk, (2013) yang menyatakan bahwa terdapat hubungan antara pekerjaan dengan tekanan darah.

Peneliti berasumsi banyak faktor yang dapat meningkatkan tekanan darah tinggi pada lansia yang masih aktif bekerja misalnya, faktor stres dalam pekerjaan, lamanya jam kerja atau lamanya waktu tempuh lokasi tempat bekerja dengan tempat tinggal. Hal itu dapat diminimalisirkan dengan cara pengelolaan management stres yang baik.

\section{Status Perkawinan}

Tabel 4 Distribusi Frekuensi Berdasarkan Status Perkawinan di RW 001 Kel. Jombang Kec. Ciputat Kota Tangerang Selatan $(\mathrm{n}=30)$

\begin{tabular}{ccc}
\hline Status Perkawinan & $\begin{array}{c}\text { Kelompok Intervensi } \\
\text { n }(\%)\end{array}$ & $\begin{array}{c}\text { Kelompok Kontrol } \\
\text { n }(\boldsymbol{\%})\end{array}$ \\
\hline Menikah & $10(66,7)$ & $11(73,3)$ \\
Janda & $5(33,3)$ & $4(26,7)$ \\
\hline Total & $\mathbf{1 5}(\mathbf{1 0 0 , 0})$ & $\mathbf{1 5}(\mathbf{1 0 0 , 0})$ \\
\hline
\end{tabular}

Berdasarkan tabel di atas, dapat diketahui bahwa 10 responden $(66,7 \%)$ dengan status perkawinan menikah dan 5 responden $(33,3 \%)$ dengan status perkawinan janda pada kelompok intervensi, sedangkan 11 responden $(73,3 \%)$ dengan status perkawinan menikah, dan 4 responden $(26,7 \%)$ dengan status perkawinan janda pada kelompok kontrol.

Secara teori orang yang sudah menikah dan masih memiliki pasangan hidup kondisi kejiwaannya relatif stabil jika dibandingkan dengan yang belum menikah atau yang sudah cerai. Disamping itu, umumnya pola makan yang menikah lebih teratur dibandingkan dengan yang belum menikah, sehingga derajat kesehatan bagi orang yang menikah akan lebih baik (Heriyanto, 2011).

Oleh sebab itu, peneliti berasumsi lansia yang berada di RW 001 Kelurahan Jombang, Kecamatan Ciputat, Kota Tangerang Selatan mayoritas masih memiliki pasangan (menikah) yang artinya hal ini tidak sejalan dengan teori di atas dan dapat diasumsikan bahwa tidak ada hubungan yang signifikan antara status perkawinan dengan kejadian hipertensi.

Gambaran Tekanan Darah Responden 
Tabel 5 Distribusi Frekuensi Hipertensi Berdasarkan Tekanan Darah Sebelum dan Sesudah Diberikan Terapi SSBM di RW 001 Kel. Jombang Kec. Ciputat Kota Tangerang Selatan ( $\mathrm{n}=30)$

\begin{tabular}{ccccccc}
\hline Variabel & Kelompok & $\mathbf{N}$ & Mean & SD & Min & Max \\
\hline Pre & Intervensi & 15 & 154,60 & 7,462 & 145 & 170 \\
Sistol & Kontrol & 15 & 166,13 & 11,438 & 145 & 193 \\
\hline Pre & Intervensi & 15 & 93,27 & 8,128 & 80 & 110 \\
Diastol & Kontrol & 15 & 92,60 & 2,898 & 88 & 98 \\
\hline Post & Intervensi & 15 & 149,33 & 7,188 & 140 & 165 \\
Sistol & Kontrol & 15 & 161,73 & 11,677 & 138 & 183 \\
\hline Post & Intervensi & 15 & 88,00 & 7,829 & 75 & 105 \\
Diastol & Kontrol & 15 & 93,00 & 3,207 & 88 & 98 \\
\hline
\end{tabular}

Tabel di atas menunjukkan bahwa tekanan darah pre sistol penderita hipertensi kelompok intervensi memiliki rata-rata (mean) $154,60 \mathrm{mmHg}$ dengan SD 7,462 dan tekanan sistol terendah yaitu $145 \mathrm{mmHg}$ dan tertinggi $170 \mathrm{mmHg}$. Hasil kelompok kontrol memiliki rata-rata (mean) 166,13mmHg dengan SD 11,438 dan tekanan sistol terendah yaitu $145 \mathrm{mmHg}$ dan tertinggi $193 \mathrm{mmHg}$. Berdasarkan tabel 12 menunjukkan bahwa tekanan darah pre diastol penderita hipertensi memiliki rata-rata (mean) 93,27mmHg dengan SD 8,128 dan tekanan diastol terendah $80 \mathrm{mmHg}$ dan tertinggi $110 \mathrm{mmHg}$. Hasil kelompok kontrol memiliki rata-rata (mean) 92,60mmHg dengan SD 2,898 dan tekanan diastol terendah $88 \mathrm{mmHg}$ dan tertinggi $98 \mathrm{mmHg}$.

Berdasarkan tabel di atas menunjukkan bahwa tekanan darah post sistol penderita hipertensi kelompok intervensi memiliki rata-rata (mean) $149,33 \mathrm{mmHg}$ dengan SD 7,188 dan tekanan sistol terendah yaitu $140 \mathrm{mmHg}$ dan tertinggi $165 \mathrm{mmHg}$. Hasil kelompok kontrol memiliki rata-rata (mean) $161,73 \mathrm{mmHg}$ dengan SD 11,677 dan tekanan sistol terendah yaitu $138 \mathrm{mmHg}$ dan tertinggi $183 \mathrm{mmHg}$. Data juga menunjukkan bahwa tekanan darah post diastol penderita hipertensi memiliki ratarata (mean) $88,00 \mathrm{mmHg}$ dengan $\mathrm{SD}$ 7,829 tekanan diastol terendah $75 \mathrm{mmHg}$ dan tertinggi $105 \mathrm{mmHg}$. Hasil kelompok kontrol memiliki rata-rata (mean) 93,00mmHg dengan SD 3,207 dan tekanan diastol terendah $88 \mathrm{mmHg}$ dan tertinggi $98 \mathrm{mmHg}$.

Nilai rata-rata tekanan darah awal responden termasuk dalam kategori hipertensi tingkat 2, seperti yang dinyatakan oleh JNC VIII (2014) yaitu tekanan darah $<120$ dan $<80 \mathrm{mmHg}$ disebut normal, tekanan darah 120-139 atau $80-89 \mathrm{mmHg}$ disebut pre-hipertensi, tekanan darah 140-159 atau $90-99 \mathrm{mmHg}$ disebut hipertensi derajat 1 dan tekanan darah $\geq 160$ atau $\geq 100 \mathrm{mmHg}$ disebut hipertensi derajat 2. Hasil penelitian ini dikuatkan dengan penelitian yang dilakukan oleh Cornelissen dan Fagard (2007) tentang Effect of Endurance Training on Blood Pressure, Blood Pressure-Regulating Mechanisms, and Cardiovascular Risk Factors didapatkan hasil dari 30 responden yang menderita hipertensi diketahui karakteristik rata-rata tekanan darah sistolik sebelum $146,7 \mathrm{mmHg}$ dan $145,4 \mathrm{mmHg}$ sesudah latihan ketahanan, sedangkan rata-rata tekanan darah diastolik sebelum 92,2mmHg dan 92,3mmHg sesudah latihan ketahanan. Peneliti berasumsi bahwa seorang lansia yang melakukan intervensi massage yang sesuai indikasi dan direkomendasikan berdasarkan nilai tekanan darah dan usia masing-masing individu, dapat menghasilkan manfaat yang maksimal untuk kesehatan lansia dengan hipertensi serta dapat meningkatkan kualitas hidup diusia senja jika dilakukan secara rutin.

\section{Uji Normalitas}


Tabel 6 Hasil Uji Normalitas Data Tekanan Darah Sistol dan Diastol Sebelum dan Sesudah Diberikan Terapi SSBM pada Kelompok Intervensi dan Kontrol di RW 001 Kel. Jombang Kec. Ciputat Kota Tangerang Selatan $(\mathrm{n}=30)$

\begin{tabular}{cccc}
\hline Variabel & Kelompok & Nilai Koefisien Skewness & Nilai Koefisien Kurtosis \\
\hline Pre & Intervensi & 0,872 & $-0,324$ \\
Sistol & Kontrol & 1,248 & 1,393 \\
\hline Pre & Intervensi & 0,452 & 0,247 \\
Diastol & Kontrol & 0,103 & $-0,145$ \\
\hline Post & Intervensi & 0,976 & 0,121 \\
Sistol & Kontrol & 0,288 & 0,270 \\
\hline Post & Intervensi & 0,457 & 0,696 \\
Diastol & Kontrol & 0,015 & $-0,586$ \\
\hline
\end{tabular}

Pada tabel di atas, menunjukkan variabel tekanan darah kelompok data intervensi dan kontrol berdasarkan nilai koefisien skewness dan kurtosis memenuhi syarat parameter $<2$. Jadi disimpulkan bahwa kelompok data tersebut berdistribusi normal. Maka penelitian ini menggunakan uji $\mathrm{T}$.

\section{Uji Homogenitas}

Tabel 7 Hasil Uji Homogenitas Data Tekanan Darah Sistol Sebelum dan Diastol Sebelum Diberikan Terapi SSBM pada Kelompok Intervensi dan Kontrol di RW 001 Kel. Jombang Kec. Ciputat Kota Tangerang Selatan $(\mathrm{n}=30)$

\begin{tabular}{cccc}
\hline Variabel & Kelompok & Pearson Correlation & P Value \\
\hline $\begin{array}{c}\text { Pre } \\
\text { Sistol }\end{array}$ & $\begin{array}{c}\text { Intervensi } \\
\text { Kontrol }\end{array}$ & 0,477 & 0,072 \\
\hline $\begin{array}{c}\text { Pre } \\
\text { Diastol }\end{array}$ & $\begin{array}{c}\text { Intervensi } \\
\text { Kontrol }\end{array}$ & 0,065 & 0,817 \\
\hline$* \alpha>0,05$ distribusi homogen & & \\
\hline
\end{tabular}

Berdasarkan tabel diatas didapatkan hasil correlation pearson didapatkan nilai r sebesar 0,477 dengan $p$ value 0,072 . Nilai $\mathrm{p}>0,05$ dan nilai $\mathrm{r}$ didapatkan positif sehingga dapat disimpulkan terdapat hubungan yang kuat antara tekanan darah sistol sebelum diberikan intervensi pada kelompok intervensi maupun kelompok kontrol. Hasil uji korelasi tekanan darah diastol didapatkan nilai r sebesar 0,065 dengan $p$ value 0,817 dan dapat disimpulkan terdapat korelasi hubungan yang kuat antara tekanan darah diastol sebelum diberikan intervensi pada kelompok intervensi maupun kelompok kontrol.

Analisis bivariat yang dilakukan adalah untuk menghubungkan masingmasing variabel independen dan variabel dependen. Sebelum melakukan analisis bivariat diperlukan uji normalitas untuk mengetahui uji yang akan dipakai selanjutnya. Berdasarkan hasil yang didapat, berarti variabel tekanan darah disimpulkan berdistribusi normal. Hasil uji normalitas tersebut maka uji yang digunakan untuk tekanan darah pre dengan tekanan darah post pada kelompok intervensi dan kelompok kontrol dilakukan dengan uji $T$ Dependent, sedangkan untuk tekanan darah sesudah pada kelompok intervensi dan kelompok kontrol serta analisis selisih menggunakan uji T-Independent. Terdapatnya pengaruh antara faktor resiko dengan tekanan darah ditunjukkan dengan nilai $\mathrm{p} \leq \alpha(0,05)$, HO ditolak, berarti data sampel mendukung adanya pengaruh yang bermakna (signifikan).

Perbedaan Tekanan Darah Sebelum dan Sesudah Dilakukan Terapi SSBM 
Tabel 8 Analisis Data Tekanan Darah Sebelum dan Sesudah Diberikan Terapi SSBM terhadap Tekanan Darah pada Kelompok Intervensi dan Kontrol di RW 001 Kel. Jombang Kec. Ciputat Kota Tangerang Selatan $(\mathrm{n}=30)$

\begin{tabular}{|c|c|c|c|c|c|c|c|c|}
\hline \multirow[t]{2}{*}{ Variabel } & \multirow[t]{2}{*}{ Kelompok } & \multirow[t]{2}{*}{$\mathbf{N}$} & \multirow[t]{2}{*}{ Mean } & \multirow[t]{2}{*}{ SD } & \multirow[t]{2}{*}{ SE } & \multirow[t]{2}{*}{ P Value } & \multicolumn{2}{|c|}{ 95\% CI } \\
\hline & & & & & & & Lower & Upper \\
\hline Pre Sistol & & 15 & 154,60 & 7,462 & 1,927 & & & \\
\hline Post Sistol & & 15 & 149,33 & 7,188 & 1,856 & 0,000 & 4,877 & 5,656 \\
\hline Pre Diastol & & 15 & 93,27 & 8,128 & 2,099 & & & \\
\hline Post Diastol & Intervensi & 15 & 88,00 & 7,829 & 2,021 & 0,000 & 4,877 & 5,656 \\
\hline Pre Sistol & & 15 & 166,13 & 11,438 & 2,953 & & & \\
\hline Post Sistol & Kontrol & 15 & 161,73 & 11,677 & 3,015 & 0,197 & $-2,567$ & 11,367 \\
\hline Pre Diastol & & 15 & 92,60 & 2,898 & 0,748 & & & \\
\hline Post Diastol & & 15 & 93,00 & 3,207 & 0,828 & 0,334 & $-1,258$ & 0,458 \\
\hline
\end{tabular}

Hasil analisis data didapatkan uji statistik untuk rata-rata tekanan darah responden terhadap kelompok intervensi untuk pre dan post sistol dengan nilai mean $154,60 \mathrm{mmHg}$ dan $149,33 \mathrm{mmHg}$, SD 7,462 dan 7,188, untuk nilai $p$ value 0,000 , sedangkan pre dan post diastol dengan nilai mean $93,27 \mathrm{mmHg}$ dan $88,00 \mathrm{mmHg}$, SD 8,128 dan 7,829, untuk diastol $p$ value 0,000 , karena nilai $\mathrm{p}<0,05$ menunjukkan adanya pengaruh yang signifikan antara sebelum dan setelah pemberian terapi slow stroke back massage.

Tekanan darah responden terhadap kelompok kontrol pada pre dan post sistol dengan nilai mean $166,13 \mathrm{mmHg}$ dan $161,73 \mathrm{mmHg}$, SD 11,438 dan 11,677, untuk $p$ value adalah 0,197 , sedangkan pre dan post diastol dengan nilai mean $92,60 \mathrm{mmHg}$ dan 93,00mmHg, SD 2,898 dan 3,207, untuk $p$ value adalah 0,334 yang berarti menunjukkan tidak adanya perubahan yang signifikan. Karena nilai $\mathrm{p}>0,05$ maka tidak menunjukkan adanya perubahan yang signifikan antara pre dan post pada kelompok kontrol.

Data ini didasari penelitian oleh Mohebbi (2014) yang berjudul "Efektifitas Back Massage terhadap Tekanan Darah pada Pasien Hipertensi Primer". Jumlah responden yang termasuk dalam penerapan tersebut berjumlah 40 responden yang dibagi atas dua kelompok, yaitu kelompok intervensi dengan 20 responden dan kelompok control dengan 20 responden. Dalam penerapan ini didapatkan hasil bahwa rata-rata tekanan darah pada kelompok intervensi setelah dilakukan terapi back massage adalah terjadi penurunan tekanan darah sistolik dan diastolik masingmasing $\quad 6,44 \mathrm{mmHg}$ dan $4,77 \mathrm{mmHg}$ $(\mathrm{p}=0,001)$ pada kelompok intervensi dan $2,31 \mathrm{mmHg}$ dan $1,51 \mathrm{mmHg}$ pada kelompok kontrol $(\mathrm{p}=0,001)$.

Hasil penerapan ini juga sesuai dengan penelitian dari Achmad Alikin (2014) dengan judul "Pengaruh Back Massage dengan Aroma Terapi Lavender terhadap Penurunan Tekanan Darah pada Lansia Hipertensi di Desa Kedungsari Kecamatan Ringinarum" didapatkan uji statistik untuk rata-rata tekanan darah responden terhadap kelompok intervensi untuk sistol $p$ value adalah 0,007 dan untuk diastol $p$ value adalah 0,031 sehingga ada pengaruh yang signifikan terhadap penurunan tekanan darah pada lansia dengan hipertensi setelah pemberian back massage dengan aroma terapi lavender. Selain itu, pada kelompok kontrol menunjukkan rata-rata tekanan darah kelompok kontrol untuk sistolik $p$ value adalah 0,482 dan diastol $p$ value adalah 0,480, dengan nilai $\mathrm{p}>0,05$ maka tidak ada menunjukkan adanya perubahan yang signifikan antara pretest dan posttest pada kelompok kontrol.

Sentuhan pada kulit ataupun tekanan langsung antara praktikkan dan pasien membuat otot, tendon dan ligamen menjadi rileks sehingga memicu pengeluaran asetilkolin melalui neurotransmitter untuk menghambat 
aktivitas saraf simpatis di miokardium, hal ini akan berpengaruh terhadap penurunan tekanan darah. Masase mempunyai kelebihan tersendiri dibandingkan dengan teknik relaksasi yang lain seperti halnya pada organ muskuloskeletal dan kardiovaskuler yang memberi efek positif pada organ. Slow stroke back masssage dapat mempengaruhi penurunan aktivitas saraf simpatis yang membuat vasodilatasi pembuluh darah dan getah bening serta meningkatkan respon refleks baroreseptor. Mekanisme ini mempengaruhi terjadinya penurunan kecepatan denyut jantung, curah jantung dan volume sekuncup dan pada akhirnya terjadi perubahan tekanan darah yaitu penurunan tekanan darah melalui memvasodilatasikan sistemik dan penurunan kontraktilitas otot jantung (Healey, 2011).

Masasage punggung atau effleurage merupakan salah satu teknik yang sejak dahulu digunakan dalam asuhan keperawatan untuk meningkatkan relaksasi dan istirahat (Adrian, 2016). Hasil riset menunjukkan bahwa massage punggung dalam waktu 3 menit dapat meningkatkan kenyamanan dan relaksasi klien serta memiliki efek positif pada kardiovaskuler seperti frekuensi denyut jantung, frekuensi pernapasan dan

tekanan darah (Berman, 2009). Selain manfaat di atas, massage juga memiliki banyak kelebihan yaitu perubahan pada sistem tubuh manusia seperti mengurangi nyeri otot, menstimulasi regenerasi sel kulit dalam membantu barrier tubuh, serta efeknya dapat menurunkan angka kejadian insomnia (Kushariyadi, 2011).

Peneliti berasumsi bahwa adanya perbedaan yang signifikan antara pre dan post pada kelompok intervensi dan kontrol yang menunjukkan bahwa intervensi slow stroke back massage mampu memberikan sentuhan pada kulit ataupun tekanan pada kulit membuat otot, tendon dan ligamen menjadi rileks sehingga meningkatkan aktivitas parasimpatis untuk mengeluarkan neurotransmitter asetilkolin untuk menghambat aktivitas saraf simpatis di otot jantung yang bermanifestasi pada penurunan tekanan darah (Retno, 2010). Selain itu, slow stroke back massage juga memiliki banyak manfaat pada sistem tubuh manusia bukan hanya pada sistem kardiovaskuler tetapi dapat mengurangi nyeri otot, dapat menstimulasi regenerasi sel kulit dalam membantu barrier tubuh, serta efeknya di sistem saraf dapat menurunkan insomnia pada lansia (Kushariyadi, 2011).

Analisis Tekanan Darah Sesudah Dilakukan Terapi SSBM

Tabel 9 Analisis Perbedaan Tekanan Darah Sesudah Diberikan Terapi SSBM pada Kelompok Intervensi dan Kontrol di RW 001 Kel. Jombang Kec. Ciputat Kota Tangerang Selatan $(\mathrm{n}=30)$

\begin{tabular}{ccccccccc}
\hline Variabel & Kelompok & $\mathbf{n}$ & Mean & SD & SE & $\boldsymbol{P}$ & $\mathbf{9 5 \%}$ & CI \\
\cline { 7 - 9 } & & & & & & Value & Lower & Upper \\
\hline TD & Intervensi & 15 & 149,33 & 7,188 & 1,856 & 0,002 & $-19,652$ & $-5,148$ \\
Sistol & Kontrol & 15 & 161,73 & 11,677 & 3,015 & & $-19,719$ & $-5,081$ \\
\hline TD & Intervensi & 15 & 88,00 & 7,829 & 2,021 & 0,034 & $-9,474$ & $-0,526$ \\
Diastol & Kontrol & 15 & 93,00 & 3,207 & 0,828 & & $-9,579$ & $-0,421$ \\
\hline
\end{tabular}

Berdasarkan tabel diatas, analisis data didapatkan uji statistik untuk ratarata tekanan darah responden terhadap kelompok post sistol intervensi dan kontrol dengan nilai mean $149,33 \mathrm{mmHg}$ dan $161,73 \mathrm{mmHg}$, SD 7,188 dan 11,677, untuk $p$ value 0,002. Sedangkan post diastol intervensi dan kontrol dengan nilai mean $88,00 \mathrm{mmHg}$ dan $93,00 \mathrm{mmHg}$, SD
7,829 dan 3,207 , untuk $p$ value 0,034 karena nilai $\mathrm{p}<0,05$ menunjukkan adanya pengaruh yang signifikan setelah pemberian intervensi slow stroke back massage pada kelompok intervensi dan kelompok kontrol.

Hasil penerapan evidence based nursing ini didasari penerapan yang dilakukan oleh Mohebbi (2014) yang 
berjudul "The Effect of Back Massage on Blood Pressure in the Patients with Primary Hypertension In 2012-2013: A Randomized Clinical Trial". Dalam penerapan ini menyatakan bahwa pemberian terapi back massage pada kelompok intervensi lebih efektif $6,44 \%$ dalam menurunkan tekanan darah sistolik dan $4,77 \%$ dalam menurunkan tekanan darah diastolik.

Efek terapi massage menimbulkan percepatan mekanisme aliran darah vena dan drainase limfatik, merusak mekanisme akumulasi patologis (misalnya, klasifikasi jaringan lunak) dan melatih jaringan lunak secara pasif. Gerakan memberi tekanan pada kulit, jaringan ikat, jaringan otot akan menimbulkan rangsangan impuls yang terletak di daerah tersebut. Impuls saraf eferen akan merangsang tubuh berreaksi melalui mekanisme reflek vasodilatasi pembuluh darah yaitu mengurangi aktivitas saraf simpatis dan meningkatkan aktifitas saraf parasimpatis, impuls tersebut dihantarkan oleh saraf aferen menuju saraf pusat dan selanjutnya susunan saraf pusat memberikan umpan balik dengan melepaskan asetilkolin dan histamin. Meningkatnya aktivitas saraf parasimpatis ini menimbulkan aktivasi respon relaksasi dengan cara menurunkan denyut jantung (heart rate) dan denyut nadi (pulse rate). Sedangkan penurunan aktivitas saraf simpatis meningkatkan vasodilatasi ateriol dan vena, yang menyebabkan resistensi vaskuler perifer menurun sehingga menurunkan tekanan darah (Sherwood, 2012).

Data yang didapatkan diatassesuai penelitian yang dilakukan Retno (2012) dengan judul "Tindakan Slow Stroke Back Massage dalam Menurunkan Tekanan Darah pada Penderita Hipertensi" didapatkan uji statistik untuk tekanan darah responden kelompok post intervensi dan kelompok post kontrol didapatkan $p$ sistolik $=0,001$ dan $\mathrm{p}$ diastolik $=0,007$ menunjukkan ada pengaruh slow stroke back massage terhadap perubahan tekanan darah pada responden. Sesuai juga dengan penelitian dari Wiyoto (2011) melaporkan efek relaksasi otot dapat mengurangi gejala tekanan darah sistolik dan diastolik, mengurangi kecemasan dan depresi, sehingga penderita hipertensi keluhannya dapat dikurangi.

Peneliti berasumsi bahwa adanya perbedaan pengaruh antara kelompok intervensi dan kelompok kontrol sesudah dilakukannya terapi slow stroke back massage yang menunjukkan bahwa terapi ini mampu memberikan rileksasi pada pasien lansia dengan hipertensi sehingga meningkatkan aktivitas parasimpatis untuk mengeluarkan neurotransmitter asetilkolin untuk menghambat aktivitas saraf simpatis diotot jantung yang bermanifestasi pada penurunan tekanan darah (Retno, 2010).

Analisis Tekanan Darah Sebelum, Pertengahan dan Sesudah Dilakukan Terapi SSBM Selama 12 Hari

Grafik 1 Analisis Tekanan Darah Sebelum, Pertengahan dan Sesudah Diberikan Terapi SSBM Selama 12 Hari pada Kelompok Intervensi dan Kontrol di RW 001 Kel. Jombang Kec. Ciputat Kota Tangerang Selatan $(n=30)$
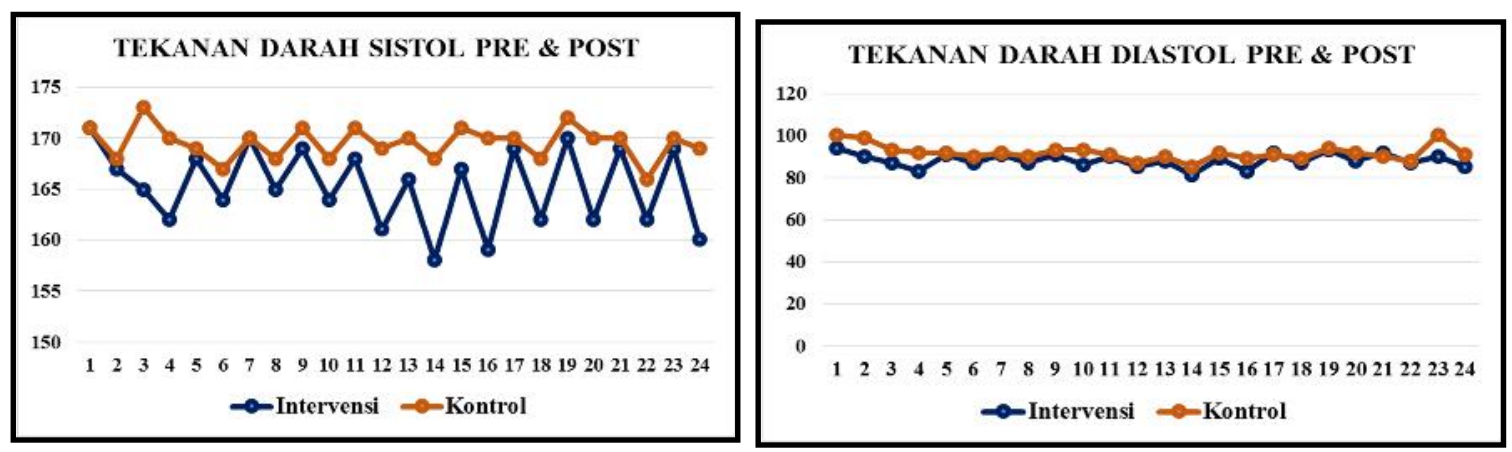
Grafik 1 menunjukkan perubahan tekanan darah sistol dan diastol pada kelompok intervensi dan kelompok kontrol sebelum dan sesudah diberikan terapi slow stroke back massage selama 12 hari yang menggambarkan rata-rata tekanan darakh efektif menurun pada hari ke 6 setelah diberikan terapi slow stroke back massage. Efektivitas perubahan tekanan darah pada hari ke 6 dikarenakan pada hari sebelumnya masih terpengaruh oleh konsumsi obat antihipertensi. Terapi ini dilakukan kepada 15 responden lansia dengan hipertensi di RW 001 Kelurahan Jombang, Kecamatan Ciputat, Kota Tangerang Selatan. Lansia dengan hipertensi di tempat tersebut mayoritas mengalami hipertensi primer yang artinya hipertensi berasal dari dampak akibat gaya hidup seseorang dan faktor lingkungan (Triyanto, 2014).

Nilai mean perubahan tekanan darah sistol dibandingkan pada kelompok intervensi dan kelompok kontrol sebelum dan sesudah diberikan terapi slow stroke back massage, yang menggambarkan rata-rata tekanan darah sistol pada kelompok intervensi menurun hingga $9 \mathrm{mmHg}$ (hari ke 12) dan perbedaannya secara statistik signifikan. Nilai rata-rata tekanan darah sistol pada kelompok kontrol juga menunjukkan penurunan $1 \mathrm{mmHg}$ (hari ke 12), tetapi perbedaannya tidak signifikan. Perbandingan perubahan nilai mean tekanan darah diastol dalam kelompok intervensi dan kelompok kontrol sebelum dan sesudah diberikan terapi slow stroke back massage, mean dari tekanan darah diastol menurun menjadi $5 \mathrm{mmHg}$ (hari ke 12) dalam kelompok intervensi dan perbedaan tersebut signifikan. Selain itu, nilai mean tekanan darah diastol menurun menjadi $2 \mathrm{mmHg}$ (hari ke 12) di kelompok kontrol, tetapi tidak terlalu signifikan.

Selama pelaksanaan terapi slow stroke back massage terhadap penurunan tekanan darah, praktikkan tidak menggunakan minyak yang berbau, berwarna dan menimbulkan rasa hangat atau dingin. Hal ini dikarenakan dapat mempengaruhi nilai tekanan darah tersebut. Fungsi minyak itu sendiri dalam penerapapi ini yaitu untuk melicinkan tubuh darn memudahkan gerakan-gerakan tangan 'selama wakmelakukan massage (Trisnowbyanto, 2012). Minyak yang berbau seperti minyak aromaterapi lavender berasal dari bunga lavender dimana bunganya berwarna lembayung muda. Minyak yang dihasilkan berasal dari bagian pucuk atau bagian paling atas bunga yang mempunyai sifat menenangkan dan memberikan kesegaran (Purwanto, 2013). Mekanisme minyak aromaterapi lavender dalam menurunkan tekanan darah yaitu dengan cara internal dan eksternal. Internal seperti ingesti dan inhalasi, sedangkan eksternal seperti massage dan hidroterapi. Metode internal dan eksternal ini dapat memberikan efek rileks pada tubuh melalui perubahan pada sistem saraf simpatis dan saraf parasimpatis (Jaelani, 2009)

\section{Kesimpulan}

Mayoritas responden pada kelompok control berada diusia pertengahan (middle age) yaitu antara 4559 tahun dengan rata-rata 57,93, berjenis kelamin perempuan yaitu sebanyak 12 responden $(80,0 \%)$, pendidikan SMA 9 responden $(60,0 \%)$, aktif bekerja 10 responden $(66,7 \%)$ dan status perkawinan menikah sebanyak 10 responden $(66,7 \%)$. Selain itu, pada kelompok kontrol terlihat bahwa mayoritas responden diusia pertengahan (middle age) yaitu antara 4559 tahun dengan rata-rata 55,69, berjenis kelamin perempuan yaitu sebanyak 9 responden $(60,0 \%)$, pendidikan SMA 12 responden $(80,0 \%)$, aktif bekerja 11 responden $(73,3 \%)$ dan status perkawinan menikah sebanyak 11 responden $(73,3 \%)$. Gambaran tekanan darah sebelum dan sesudah dilakukan terapi slow stroke back massage pada kelompok intervensi terlihat bahwa rata-rata pre sistol $(154,60 \mathrm{mmHg}), \quad$ post sistol $(149,33 \mathrm{mmHg})$ dan pre diastol 
$(93,27 \mathrm{mmHg}), \quad$ post diastol $(88,00 \mathrm{mmHg})$. Pada kelompok kontrol terlihat bahwa rata-rata pre sistol $(166,13 \mathrm{mmHg}), \quad$ post sistol $(161,73 \mathrm{mmHg})$ dan pre diastol $(92,60 \mathrm{mmHg})$, post diastol $(93,00)$.

Analisis perbedaan tekanan darah sebelum dan sesudah dilakukan terapi slow stroke back massage pada kelompok intervensi didapatkan hasil $p$ value 0,000 (pre dan post sistol) dengan $\alpha<0,05$ dan $p$ value 0,000 (pre dan post diastol) dengan $\alpha<0,05$ yang artinya ada pengaruh yang signifikan terhadap tekanan darah antara sebelum dan sesudah pemberian terapi slow stroke back massage. Hasil pada kelompok kontrol $p$ value 0,197 (pre dan post sistol) dengan $\alpha>0,05$ dan $p$ value 0,334 (pre dan post diastol) dengan $\alpha>0,05$ yang artinya tidak ada pengaruh yang signifikan terhadap tekanan darah antara sebelum dan sesudah. Ada perbedaan yang signifikan sesudah dilakukan terapi slow stroke back massage pada kelompok intervensi dan kelompok kontrol didapatkan hasil $p$ value 0,002 (sistol) dengan $\alpha<0,05$ dan $p$ value 0,034 (diastol) dengan $\alpha<0,05$.

Berdasarkan hasil selama proses penelitian yang dilakukan, yang perlu direkomendasikan untuk lansia yang mengalami hipertensi perlu dilakukkannya terapi slow stroke back massage selama 6 kali dalam waktu 2 minggu untuk menurunkan tekanan darah agar mencegah komplikasi akibat hipertensi. Bagi keluarga dengan anggota keluarga lansia perlu ditingkatkan dalam memotivasi lansia yang mengalami hipertensi, agar lansia tersebut mendapat dukungan dari anggota keluarga dalam menurunkan tekanan darah khususnya dengan terapi slow stroke back massage. Selain itu, perlu dilakukan penelitian lebih lanjut misalnya terkait program intervensi terpadu untuk lansia hipertensi dengan didalamnya terdapat beberapa intervensi terkait pengontrolan obat antihipertensi, diet yang dikonsumsi, aktivitas yang dilakukan, yang dapat mempengaruhi perubahan sistem kardiovaskuler.

\section{Daftar Psutaka}

[1] Admin, 2011, Pria lebih rentan terkena hipertensi dari pada wanita, Graha Ilmu, Yogyakarta

[2] Agus, R 2010, Aplikasi metodologi penelitian kesehatan, Nuha Medika, Yogyakarta

[3] Alikin, A 2014, 'Pengaruh Back Massage dengan Aroma Terapi Lavender terhadap Penurunan Tekanan Darah pada Lansia Hipertensi', Ilmu Keperawatan dan Kebidanan, vol.4, no.4, Februari 2014

[4] Alwi Hasan dkk, 2007, Kamus besar bahasa Indonesia, Departemen Pendidikan Nasional Balai Pustaka, Jakarta

[5] Andria, Kiki Melissa, 2013, 'Hubungan antara Perilaku Olahraga, Stres dan Pola Makan dengan Tingkat Hipertensi pada Lanjut Usia di Posyandu Lansia Kelurahan Gebang Putih Kecamatan Sukolilo Kota Surabaya', Promkes, vol.1, no.2, Desember 2013

[6] Anggara dkk, 2013, 'Faktor-Faktor yang Berhubungan dengan Tekanan Darah di Puskesmas Telaga Murni, Cikarang Barat Tahun 2012', Ilmiah Kesehatan, vol.5, no.1, Januari 2013

[7] Ardiansyah, M 2012, Medikal bedah. Diva Prest, Yogyakarta

[8] Ayu, HA \& Komang, 2011, Asuhan keperawatan komunitas : teori \& praktik, EGC, Jakarta

[9] Aziz, AH 2007, Metode penelitian dan teknik analisis data, Salemba Medika, Jakarta

[10] Azizah, LM 2011, Keperawatan lanjut usia, Graha Ilmu, Yogyakarta

[11] Badan Penelitian dan Pengembangan Kesehatan, 2013, Riset kesehatan dasar 2013, Kementerian Kesehatan Republik Indonesia

[12] Bapenkes, Depkes RI, 2009, Riset kesehatan dasar (Riskesdas) 2007, Jakarta 
[13] Bapenkes, Depkes RI, 2010, Riset kesehatan dasar (Riskesdas) 2013, Jakarta

[14] Berman, A 2009, Buku ajar praktik keperawatan klinis, EGC, Jakarta

[15] Casanelia, L 2010, Fundamental of massage third edition national library of Australia catatoguing-inpublication data, Elsevier

[16] Cassar, R 2007, Panduan sehat sembuhkan penyakit dengan pijat dan herbal, Indonesia, Yogyakarta

[17] Dahlan, S 2008, Statistik untuk kedokteran dan kesehatan, Salemba Medika, Jakarta

[18] Dalimartha, S dr. dkk, 2008, Care your self hipertension. Penebar Plus, Jakarta

[19] Damayanti, Aniroh \& Priyanto, 2014, 'Perbedaan Tekanan Darah Sebelum dan Sesudah Dilakukan Hidroterapi Rendam Hangat pada Penderita Hipertensi di Desa Kebondalem Kecamatan Jambu Kabupaten Semarang', Ilmiah Kesehatan, vol.5, no.1, Januari 2014

[20] Fatmah, 2010, Gizi usia lanjut, Erlangga, Jakarta

[21] Garnadi, Y 2012, Hidup nyaman dengan hipertensi, Agromedia Pustaka, Jakarta

[22] Gibson, J 2007, Fisiologi dan anatomi modern untuk perawat, EGC, Jakarta

[23] Gunawan, L 2007, Hipertensi tekanan darah tinggi, Penerbit Kanisius, Yogyakarta

[24] Guyton AC, Hall JE, 2007, Buku ajar fisiologi kedokteran, EGC, Jakarta

[25] Hartanto, B 2011, Hipertensi : the silent killer. Perhimpunan Hipertensi Indonesia

[26] Hastono, SP 2010, Analisis data kesehatan fakultas kesehatan masyarakat universitas Indonesia, Universitas Indonesia, Jakarta

[27] Herlambang, 2013, Melakukan hipertensi \& diabetes, PT. Suku Buku, Jakarta
[28] Hidayat, AAA \& Uliyah, M 2008, Buku saku praktikum kebutuhan dasar manusia, EGC, Jakarta

[29] Indraswara, dkk 2009, Tekanan darah antara pria dan wanita hipertensi yang mengalami obesitas tingkat II. Poliklinik Jantung : RS. Saiful Anwar. Malang

[30] J.Guldsznudt, Adrian dkk 2013, Stroke esensial, PT Indeks, Jakarta

[31] Jain, R 2011, Pengobatan alternatif untuk mengatasi tekanan darah. PT. Gramedia Pustaka Utama, Jakarta

[32] JNC 8, 2014, Hypertension Guidelines : An In-Depth Guide The American Journal of Managed Care

[33] Junaedi, E dkk, 2013, Hipertensi kandas berkat herbal. F.Media (Imprint Agro Media Pustaka), Jakarta

[34] Kartikasari, 2012, Analisis faktor risiko penyakit hipertensi, Riset Pembinaan Tenaga Kesehatan, Kementerian Kesehatan Republik Indonesia

[35] Kelana, KD 2011, Metodologi penelitian keperawatan (pedoman melaksanakan dan menerapkan hasil penelitian, Trans Info Media, Jakarta

[36] Kemenkes, Depkes RI, 2013, Riset kesehatan dasar (Riskesdas) 2013, Jakarta

[37] Khoiriyah, N 2011, 'Faktor-Faktor yang Berhubungan dengan Motivasi Lansia Berkunjung ke Posyandu Lansia di RW 11 Kelurahan Margorejo Kecamatan Cepiring Kabupaten Kendal', Keperawatan, vol.7 no.4, September 2011

[38] Kowalski, RE 2010, The blood pressure cure: 8 weeks to lower blood pressure without prescription drugs, Qanita, Bandung

[39] Kozier, Barbara, Erb, Glenora, Berman, Audrey, Snyder, Shirlee J, 2009, Fundamental of nursing cincept, process and practice seventh edition, person education, new jersey 
[40] Kushariyadi, 2011, Asuhan keperawatan klien lanjut usia, Salemba Medika, Jakarta

[41] Meneg PP \& PA, 2009, Angka harapan hidup berdasarkan provinsi, Jakarta

[42] Mohebbi, Zinat dkk, 2014, The Effect of Back Massage on Blood Pressure in The Patients with Primary Hypertension. IJCBNM, vol.2 no.4, University of Medical Sciences

[43] Mubarak, WI dkk, 2007, Promosi kesehatan sebuah pengantar proses belajar mangajar dalam pendidikan, Graha Ilmu, Yogyakarta

[44] Muhammadun, AS 2010, Hidup bersama hipertensi serangan darah tinggi sang pembunuh sekejap, InBooks, Yogyakarta

[45] Mujahidullah, K 201, Keperawatan gerontik, Pustaka Pelajar, Yogyakarta

[46] Murwani, S 2010, Asuhan keperawatan keluarga, Mitra Cendik, Yogyakarta

[47] Mutaqin, A 2009, Asuhan keperawatan klien dan gangguan sistem kardiovaskuler, Salemba Medika, Jakarta

[48] Notoatmodjo, S 2014, Metodologi penelitian kesehatan, Rineka Cipta, Jakarta

[49] Nurrahmani, U 2012, Stop hipertensi, Familia, Yogyakarta

[50] Nursalam, 2008, Konsep dan penerapan metodelogi penelitian ilmu keperawatan, Salemba Medika, Jakarta

[51] Potter and Perry, 2005, Buku ajar fundamental keperawatan : konsep, proses dan praktik, EGC, Jakarta

[52] Pradono, J 2010, 'Faktor-Faktor yang Mempengaruhi Terjadinya Hipertensi di Daerah Perkotaan (Analisis Data Riskesdas 2007)' Gizi Indonesia 2010, vol.33 no.1

[53] Prasetyorini, dkk, 2012, 'Stres pada Penyakit terhadap Kejadian Komplikasi Hipertensi pada Pasien Hipertensi', STIKES, vol.5 no.1, Juli 2012
[54] Purwanto, B 2013, Herbal dan keperawatan komplementer (teori, praktik, hukum dalam asuhan keperawatan), Nuha Medika. Jakarta

[55] Retno, \& Prawesti, 2012, 'Tindakan Slow Stroke Back Massage dalam Menurunkan Tekanan Darah dalam Menurunkan Tekanan Darah pada Penderita Hipertensi'. Stikes, vol.5 no.2, Stikes RS Baptis Kediri

[56] Riyadi, S 2012, Keperawatan medikal bedah, Pustaka Pelajar, Yogyakarta

[57] Saputro, FD 2013, 'Pengaruh Pemberian Masase Punggung terhadap Tekanan Darah pada Pasien Hipertensi', STIKES, Semarang

[58] Sarwonto, E, Rahajeng \& Tuminah, 2009, Prevalensi hipertensi dan determinannya di Indonesia. Pusat Penelitian Biomedis dan Farmasi, Jakarta

[59] Setyawati, A 2010, 'Pengaruh Relaksasi Otogenik terhadap Kadar Gula Darah dan Tekanan Darah pada Klien Diabetes Millitus Tipe 2 dengan Hipertensi di Instalasi Rawat Inap Rumah Sakit di D.I.Y dan Jawa Tengah', Fakultas Ilmu Keperawatan, Universitas Indonesia

[60] Sheps, Sheldon, G, 2011, Mayo clinic hipertension, mengatasi tekanan darah tinggi, PT Intisari Mediatama, Jakarta

[61] Sherwood, L 2012, Fisiologi manusia dari sel ke system, EGC, Jakarta

[62] Shinta, AAA, 2014, 'Pemberian Intervensi Slow Stroke Back Massage Menurunkan Tekanan Darah pada Wanita Middle Age dengan Kondisi Pre-Hypertension', Program Studi Fisioterapi Fakultas Kedokteran Uviversitas Udayana, Bali

[63] Sigarlaki, H 2007, 'Karakteristik dan Faktor Berhubungan dengan Hipertensi di Desa Bocor, Kecamatan Bulus Pesantren, Kabupaten Kebumen, Jawa Tengah', MAKARA KESEHATAN, vol.10 no.2, Desember 2007 
[64] Smeltzer, Suzanne C., Bare, Brenda G., Hinkle, Janice L., \& Cheever, Kerry H 2010, Brunner \& Suddarth`s Textbook Of Medical Surgical Nursing. $12^{\text {th }}$ edition, Philadelphia, Wolters Kluwer

[65] Soewolo, dkk 2011, Petunjuk praktikum fisiologi manusia, JICA, Malang

[66] Stanley \& Beare, 2007, Buku ajar keperawatan gerontik, EGC, Jakarta

[67] Triyanto, E 2014, Pelayanan keperawatan bagi penderita hipertensi secara terpadu, Graha Ilmu, Yogyakarta

[68] Udjuanti, JW 2010, Keperawatan kardiovaskuler, Salemba Medika, Jakarta

[69] Wahyuningsih, RS 2013, Penatalaksanaan diet pada pasien, Graha Ilmu, Yogyakarta

[70] Wahyunita, VD \& Fitrah, 2010, Memahami kesehatan pada lansia, Trans Info Media, Jakarta

[71] World Health Organization, 2010, Global atlas on cardiovascular disease prevention and control, Geneva

[72] Yeni, dkk 2010, 'Faktor-Faktor yang Berhubungan dengan Kejadian Hipertensi pada Wanita Usia Subur di Puskesmas Umbulharjo I Yogyakarta Tahun 2009', Fakultas Kesehatan Masyarakat Universitas Ahmad Dahlan, vol.4 no.2, Juni 2010

[73] Yulianti, dkk 2013, Asuhan kebidanan 3 (menopause), Trans Info Media, Jakarta

[74] Zuliani, dkk 2013, 'Pengaruh Stimulasi Kataneus (Slow Stroke Back Massage) terhadap Penurunan Nyeri Haid (Dismenore)', Jurnal Eduhealt, vol.3 no.2

[75] Zuraidah, Maksus, \& Apriliadi, N 2012, 'Analisis Faktor Risiko Penyakit Hipertensi pada Masyarakat di Kecamatan Kemuning Kota Palembang Tahun 2012', Palembang, Riset Pembinaan Tenaga Kesehatan, Kementerian Kesehatan Republik Indonesia. 